\title{
Records of Holopedium gibberum Zaddach, 1855 (Crustacea: Cladocera) in the floodplain lakes of the Kerzhensky Nature Reserve (Nizhny Novgorod region, Russia)
}

\author{
V.S. Zhikharev, G.V. Shurganova, I.A. Kudrin \\ Lobachevsky State University of Nizhny Novgorod, Gagarin Av. 23, Nizhny Novgorod, Russia, \\ 603950.E-mail: slava.zhiharev@ro.ru
}

ABSTRACT: The paper summarizes data on the representative of the northern faunistic cladoceran complex, Holopedium gibberum Zaddach, 1855, found in the floodplain lakes of the middle course of the Kerzhenets River (Kerzhinsky Nature Reserve, Nizhny Novgorod region, Russia). The list of localities of this species has been expanded. The populations of $H$. gibberum were mostly confined to the pelagic zone of low-mineralized lakes. Density of $H$. gibberum in the littoral zone with macrophytes decreased considerably. Data on the ecological preferences of this species has been updated.

How to cite this article: Zhikharev V.S., Shurganova G.V., Kudrin I.A. 2019. Records of Holopedium gibberum Zaddach, 1855 (Crustacea: Cladocera) in the floodplain lakes of the Kerzhensky Nature Reserve (Nizhny Novgorod region, Russia) // Invert. Zool. Vol.16. No.3. P.305-309. doi: 10.15298/invertzool.16.3.08

KEY WORDS: Cladocera, biodiversity, nature reserve, floodplain lakes, environmental preferences, Holopedium gibberum, Nizhny Novgorod Region.

\section{Находки Holopedium gibberum Zaddach, 1855 (Crustacea: Cladocera) в пойменных озерах Керженского заповедника (Нижегородская область, Россия)}

\section{В.С. Жихарев, Г.В. Шурганова, И.А. Кудрин}

Нижегородский государственный университет им. Н.И. Лобачевского, пр. Гагарина 23, Нижний Новгород, Россия, 603950. E-mail: slava.zhiharev@ro.ru

РЕЗЮМЕ: В статье обобщены данные о представителе северного фаунистического комплекса ветвистоусых ракообразных Holopedium gibberum Zaddach, 1855, обнаруженного в пойменных озёрах среднего течения р. Керженец (Керженский заповедник, Нижегородская область, Россия). Расширен список местообитания этого вида. Было установлено, что популяции $H$. gibberum в основном ограничены пелагической зоной слабоминерализованных озёр, тогда как в заросшей литоральной зоне его численность значительно уменьшалась. Уточнены представления об экологических предпочтениях этого вида.

Как цитировать эту статью: Zhikharev V.S., Shurganova G.V., Kudrin I.A. 2019. Records of Holopedium gibberum Zaddach, 1855 (Crustacea: Cladocera) in the floodplain lakes of 
the Kerzhensky Nature Reserve (Nizhny Novgorod region, Russia) // Invert. Zool. Vol.16. No.3. P.305-309. doi: 10.15298/invertzool.16.3.08

КЛЮЧЕВЫЕ СЛОВА: Cladocera, биоразнообразие, природный заповедник, пойменные озёра, экологические предпочтения, Holopedium gibberum, Нижегородская область.

\section{Introduction}

Holopedium gibberum Zaddach, 1855 is the representative of the cladoceran northern faunistic complex (Figs 1-3). It has a Holarctic distribution (Kotov et al., 2013) being characteristic of subarctic and temperate climates (Korovchinsky, 2005). H. gibberum is widely distributed in the lakes of North-Western Europe and further to the east in the boreal zone of Northern Eurasia from Iceland to the northeast of Siberia and north-west of North America. Latitudinally, this species is known from the Arctic zone to the mountain lakes in the Alps and Pyrenees, the Amur River basin, and South Korea. Isolated populations occur in the Himalayan lakes (Rowe et al., 2007; Korovchinsky, 2018).

In the Volga River basin, H. gibberum is found in a relatively few lakes. The main localities of this species are situated in the Middle
Volga River basin: Republics of Mari El, Chuvashia and Tatarstan, Ulyanovsk and Nizhny Novgorod regions (Bayanov, Yulova, 2001; Podshivalina, 2012; Podshivalina et al., 2012; Red Data Book..., 2014; Il'in, 2016).

In the lakes of the Kerzhinsky Nature Reserve, $H$. gibberum was originally found in small number in 2001 in deep Pustynnoe, Krugloe and Cherny Yar lakes situated in the center of reserve and far from the river (Bayanov, Frolova, 2001; Bayanov, Yulova, 2001).

$H$. gibberum is a mass form of pelagic plankton inhabiting lakes with low in Calcium content (usually no more than $25 \mathrm{mg} / \mathrm{l}$ ), low in conductivity, $\mathrm{pH}=4.0-7.5$ and maximum temperature up to $+25^{\circ} \mathrm{C}$ (Korovchinsky, 2018). Holopediums are capable of forming moving shoals (Korovchinsky, 2004).

The species is listed in the Red Data Book of the Nizhny Novgorod Region (category B2 rare species that are located on the border of the
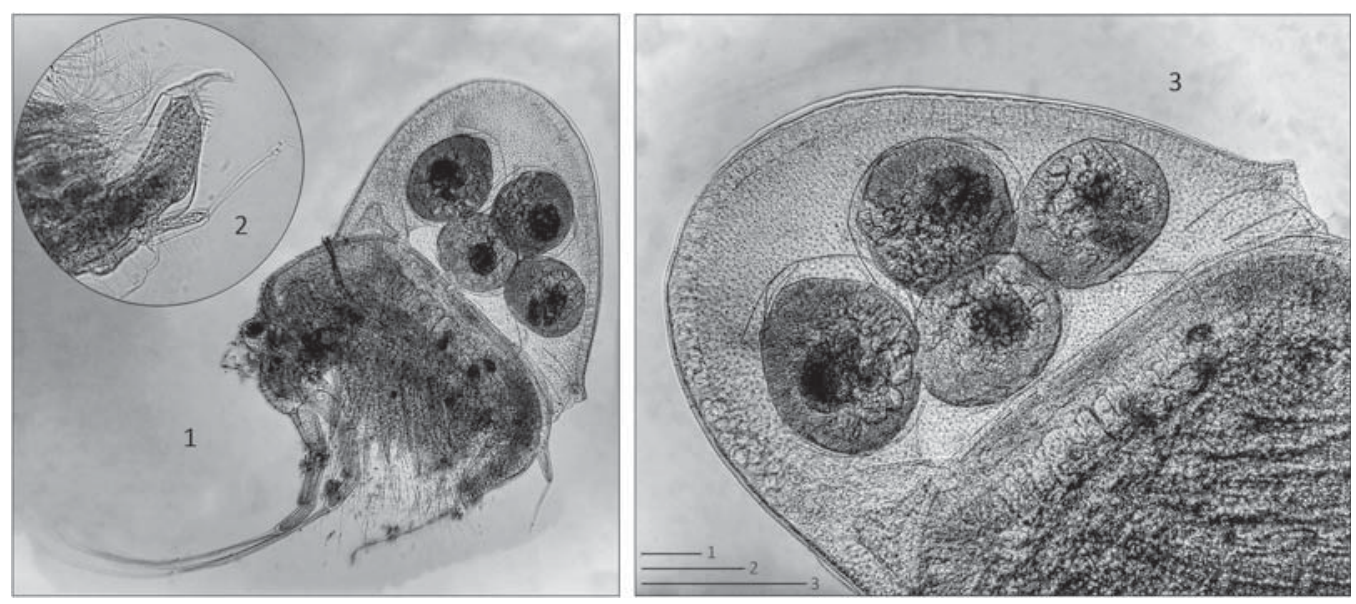

Fig. 1-3. Holopedium gibberum Zaddach, 1855, female, photo: V.S. Zhikharev, July 2018. 1 - external lateral view; 2 - postabdomen; 3 - eggs in the brood pouch. Scale bars $200 \mu \mathrm{m}$.

Рис. 1-3 . Holopedium gibberum Zaddach, 1855, самка, фото: В.С. Жихарев, июль 2018.

1 - внешний вид сбоку; 2 - постабдомен; 3 - яйца в выводковой камере. Масштаб: 200 мкм. 
range), as well as in other regional Red Books. The species disappears in the early stages of degradation of lake ecosystems under the influence of pollution and anthropogenic eutrophication. Therefore, it is very important to identify habitats with Holopedium to establish a protective regime against water pollution, eutrophication, etc. (Red Data Book ..., 2014).

The finding of $H$. gibberum in the lakes of the region is important for nature conservation. Generally, the floodplain lakes of the Kerzhinsky Nature Reserve are poorly studied. The results of the present paper will be important for «Chronicle» of the Kerzhinsky reserve, and new data on findings of $H$. gibberum will increase knowledge about the distribution of the species on the border of its range and its ecological preferences.

The paper aims summarize information on environmental preferences of the newly recorded cladoceran $H$. gibberum found in shallow floodplain lakes of the middle part of the Kerzhenets River.

\section{Study area, Material and Methods}

Specially protected natural areas, in particular natural reserves, are created for protection and study either of the unique or typical ecosystems (Derevenskaya, Unkovskaya, 2016). The territory of the Kerzhinsky Nature Reserve is located in the Low Transvolgian part of the Nizhny Novgorod region. The main water artery of the reserve is the Kerzhenets River - the left tributary of the Volga River in the region of Cheboksary reservoir. It is $290 \mathrm{~km}$ long river, $33.4 \mathrm{~km}$ of the middle part of which are included in the Kerzhinsky Nature Reserve (Fridman, Korablyova, 2001). On the left bank of the Kerzhenets River, is a large number of floodplain shallow lakes, which are currently insufficiently studied.

This paper presents the results of research carried out in 2017 of floodplain lakes located on the left coast of the middle part of the Kerzhenets River. All lakes are located on the territory of the Kerzhinsky Nature Reserve. These are small (area 2.3-5.7 ha), dystrophic- oligotrophic, clearly stratified shallow lakes (depth 0.7-2.5 m). These lakes have low electrical conductivity $(29.0-63.5 \mu \mathrm{S} / \mathrm{cm})$, high water color (178.7-655.7 deg), low content of dissolved oxygen (0.9-5.2 mg/1), low pH (5.4-6.8) and rather high water turbidity $(3.3-18.4 \mathrm{mg} / \mathrm{l})$.

Zooplankton samples were collected in summer 2017 once a month in areas with a depth of more than $2 \mathrm{~m}$ (three sampling stations in the lake) by total catches from the bottom to the surface with the nylon mesh net (70 $\mu \mathrm{m}$ mesh), 1001 of water were filtered into shallow water and fixed with $4 \%$ formalin solution. The material was processed according to standard methods (Guidelines for the collection..., 1982).

\section{Results}

In total, $H$. gibberum was found in five floodplain lakes: Sirotinnoe Lake (N56.47587 ${ }^{\circ}$, E44.81320 $)$, Krasnyj Yar Lake (N56.45011 ${ }^{\circ}$, E44.84677 $)$, Chyornyj Yar Lake(N56.43775 ${ }^{\circ}$, E44.85215 $)$, Chernozyorskoe-1 Lake (N56. $43550^{\circ}, \mathrm{E} 44.85623^{\circ}$ ) and Chernozyorskoe-2 Lake (N56.43109 ${ }^{\circ}, \mathrm{E} 44.86351^{\circ}$ ).

During June and July 2017, the quantitative development of $H$. gibberum in the studied lakes differed significantly (Table 1). In June, during the period of the highest water level, density of $H$. gibberum was relatively high only in Chyornyj Yar Lake $\left(9.41 \times 10^{3}\right.$ ind. $\left./ \mathrm{m}^{3}\right)$ and Chernozerskoye-1 Lake $\left(16.47 \times 10^{3}\right.$ ind. $\left./ \mathrm{m}^{3}\right)$. However, H. gibberum did not dominate in these lakes.

In July, during the period of the lowest water level, the density of $H$. gibberum reached its maximum (Table 1). In these lakes it was one of the dominant species of zooplankton, accounting for 27.6 and $25.5 \%$, respectively of the total zooplankton density. This time, the species was also recorded for the first time in Sirotinnoe Lake, whereas, it was not found in lakes Krasny Yar and Chernozerskoe-1, in which it was found in June. In September, H. gibberum was not detected in any of the studied lakes.

Generally, the population density of $H$. gibberum varied considerably in the studied reservoirs. The maximum density of this species was 
Table 1. Density of Holopedium gibberum in lakes of the Kerzhinsky Nature Reserve.

Таблица 1. Плотность Holopedium gibberum в озёрах Керженского Природного заповедника.

\begin{tabular}{|l|c|c|c|c|}
\hline \multirow{2}{*}{ Lake } & \multicolumn{2}{|c|}{ June } & \multicolumn{2}{c|}{ July } \\
\cline { 2 - 5 } & $\begin{array}{c}\text { Density, } \\
\times 10^{3} \text { ind./m }\end{array}$ & $\begin{array}{c}\text { \% of the total } \\
\text { zooplankton } \\
\text { density }\end{array}$ & $\begin{array}{c}\text { Density, } \\
\times 10^{3} \text { ind. } / \mathrm{m}^{3}\end{array}$ & $\begin{array}{c}\% \text { of the total } \\
\text { zooplankton } \\
\text { density }\end{array}$ \\
\hline Sirotinnoe & - & - & 1.70 & 3.6 \\
\hline Krasnyj Yar & 0.20 & 0.2 & - & - \\
\hline Chyornyj Yar & 9.41 & 1.8 & 21.93 & 27.6 \\
\hline Chernozyorskoe-1 & 16.47 & 3.4 & 17.03 & 25.5 \\
\hline Chernozyorskoe-2 & 0.04 & 0.01 & - & - \\
\hline
\end{tabular}

recorded in a lake (Table 1$)$ with a high content of suspended substances $(15.5 \mathrm{mg} / \mathrm{l})$, water color $(655.7 \mathrm{deg}$.) and acidity ( $\mathrm{pH}=5.9)$, as well as low electrical conductivity of water $(29.0 \mu \mathrm{S} /$ $\mathrm{cm})$, and, mineralization. In addition, populations of $H$. gibberum in all studied lakes were concentrated in the pelagic zone, which density decreased (on average, in 1.5 times) in the littoral zone, overgrown with macrophytes. Horizontal distribution $H$. gibberum probably depends on similarity of the lake (for example, the littoral zone) parts with pelagic zone.

\section{Discussion}

The finding of $H$. gibberum in the shallow, well-warmed lakes of the plain taiga forest landscape (left bank of the middle course of the Volga River) indicated broader ecological preferences of this species. The maximum density of H. gibberum was in July in lakes with high water temperature (Chyornyj Yar Lake $-24.6 \pm 0.09^{\circ} \mathrm{C}$ and Chernozyorskoe-1 Lake $-22.4 \pm 0.3{ }^{\circ} \mathrm{C}$ ), this did not correlate with the typical preferences of this species (see Korovchinsky, 2004, 2018; Podshivalina, 2012; Podshivalina et al., 2012). Apparently, period of the maximum density of $H$. gibberum in the floodplain lakes of the southern border of taiga biome (left bank of the middle course of the Volga River) has different time limits.

Previous records of $H$. gibberum on the territory of the Kerzhinsky Nature Reserve were confined to deep-water lakes, which are typical habitats of this northern species. New data on the habitat of $H$. gibberum in shallow floodplain lakes suggests that such lakes are quite attractive habitats. This is probably due to the low electrical conductivity of water and their acquisition of secondary oligotrophic features during the aging of water bodies (Podshivalina, 2012). The floodplain lakes certainly deserve further study as a new poorly studied biotope of the habitation of $H$. gibberum on the border of range. The lakes of the Kerzhinsky Nature Reserve can become model habitats for studying the ecological preferences of this species in the southern border of taiga biome.

\section{Conclusions}

According to the results of the 2017 research, in the floodplain lakes of the Kerzhinsky Nature Reserve, four new localities of the northern cladoceran H. gibberum were found. These results make it possible to recommend these lakes inhabited by rare species $H$. gibberum for inclusion in the Red Data Book of Nizhny Novgorod region.

The findings of this study are partially consistent with data previously published (Podshivalina, 2012; Podshivalina et al., 2012). Importantly, our results provide evidence for that on the southern border of its range in shallow floodplain lakes $H$. gibberum, probably, prefers predominantly the open pelagic zone of slightly mineralized lakes over lakes littoral zone, overgrown with macrophytes. In fact, H. gibberum is able to use thickets of macrophytes as a refuge from planktivorous fish species (Podshivalina 
et al., 2012). The investigated lakes have scarce fish fauna. A predation pressure on $H$. gibberum may be minimal, accordingly it is not necessary to use overgrown littoral as a refuge in the lakes studied. That's probably why H. gibberum in these lakes prefers the pelagic zone. This may constitute the object of future studies.

\section{References}

Bayanov N.G., Frolova E.A. 2001. [The fauna of hydrobionts of the Kerzhensky Reserve] // Trudyi gosud. prirodn. zapov. "Kerzhenskiy". Vol.1. P.251-286 [In Russian].

Bayanov N.G., Yulova G.A. 2001. [To the question of the origin and current ecological state of some lakes of the Nizhny Novgorod Trans-Volga region] // Vestnik Nizhegorodskogo gosudarstvennogo universiteta im. N.I. Lobachevskogo. Seriya Biologiya. No.1(2). P.91102 [in Russian, with English summary].

Derevenskaya O.Y., Unkovskaya E.N. 2016. [The structure of zooplankton communities of the lakes of the Volga-Kama reserve] // Trudy Zoologicheskogo instituta RAN. Vol.320. No.3. P.294-303 [in Russian, with English summary].

Fridman B.I., Korablyova O.V. 2001. [Geology and relief of the Kerzhensky Reserve] // Trudy gosud. prirodn. zapov. "Kerzhenskiy". Vol.1. P.7-70 [in Russian].

Il'in M.Yu. 2016. [Composition and structure of zooplankton communities of water bodies of specially protected natural territories (on the example of the Nizhny Novgorod region)]. Dissertatsiya na soiskanie uchenoi stepeni kandidata biologicheskikh nauk: 03.02.08. Nizhnij Novgorod. 227 p. [In Russian]

Korovchinskiy N.M. 2004. [Crustacean crustaceans of the Ctenopoda order of the world fauna (morphology, systematics, ecology, zoogeography)]. Moscow: KMK Scientific Press. 410 p. [In Russian]

Korovchinsky N.M. 2005. New species of Holopedium Zaddach, 1855 (Crustacea: Cladocera: Ctenopoda) from Greenland // Journal of Limnology. Vol.64. No.2. P.1-10.

Korovchinsky N.M. 2018. Cladocera: Ctenopoda. Families Sididae, Hopopedidae \& Pseudopenilidae (Brachiopoda: Cladocera) // Identification Guides to the plankton and benthos of Inland waters. Weikersheim: Margraf Publishers GmbH. 204 p.

Kotov A., Forró L., Korovchinsky N.M., Petrusek À. 2013. World checklist of freshwater Cladocera species // World Wide Web electronic publication. Available online at http://fada.biodiversity.be/group/show/

[Red Data Book of Nizhny Novgorod region.] Vol.1. 2014. 446 p. [In Russian]

[Guidelines for the collection and processing of materials for hydrobiological studies in freshwater bodies. Zooplankton and its products]. 1982. Leningrad. [In Russian]

Podshivalina V.N. 2012. [Peculiarities of biology and distribution of Holopedium gibberum (Crustacea, Cladocera) in the territory of the South Taiga region of the Low Volga] // Povolzhskiy ekologicheskiy zhurnal. No.3. P.295-301 [in Russian, with English summary].

Podshivalina V.N., Sheveleva N.G., Bayanov N.G. 2012. Biology and Ecology of Holopedium gibberum (Branchiopoda: Cladocera: Ctenopoda) in the Palearctic // Hydrobiological Journal. Vol.48. No.4. P.28-36.

Rowe C.L., Adamowicz S.J., Hebert P.D.N. 2007. Three new cryptic species of the freshwater zooplankton genus Holopedium (Crustacea: Branchiopoda: Ctenopoda), revealed by genetic methods // Zootaxa. Vol.1656. P.1-49.

Responsible editor A.Yu. Sinev 